\title{
SA PANGAMBE SA PANAILI "SEBUAH KARYA TARI TERINSPIRASI DARI RITUAL MARPANGIR DI KABUPATEN MANDAILING NATAL"
}

\author{
Rasmida $^{1^{*}}$, Sahrul N ${ }^{2 *}$, Siti Pratiwi Agmaulida Fatrion ${ }^{3 *}$ \\ Pengkajian dan Penciptaan Seni Program Pascasarjana \\ Institut Seni Indonesia Padangpanjang \\ Jl. Bahder Johan, Guguak Malintang, Padangpanjang, Kota Padangpanjang, Kode Pos 27126 \\ Sumatera Barat. Indonesia \\ Email: rasmidararas@yahoo.com,sahrul@yahoo.com,tiwichan2@gmail.com
}

\begin{abstract}
Abstrak
Masyarakat Kabupaten Mandailing Natal memiliki tradisi yang dilakukan nenek moyang pada zaman dahulu salah satunya ritual Marpangir. Marpangir artinya kegiatan membersihkan diri dalam menyambut bulan suci Ramadhan. Kegiatan Marpangir ini memiliki nilai-nilai, seperti nilai budaya, nilai etika, nilai agama dan nilai sosial. Seiiring berkembangnya zaman ritual Marpangir ini sudah mulai berubah cara melakukan dan bahan yang digunakan. Hal ini menimbulkan keprihatinan pengkarya dalam melihat fenomena pergeseran nilai yang terjadi pada muda-mudi saat ini sehingga berpengaruh terhadap sikap dari muda-mudi yang individualisme. Fenomena ini diinterpretasikan dan diekspresikan melalui karya tentang keprihatinan pengkarya terhadap pergerseran nilai dari ritual Marpangir ini. Padahal dulu muda-mudi di Kabupaten Mandailing Natal memiliki sikap kebersamaan yang kuat sehingga hadir ungkapan "Sa Pangambe Sa Panaili". Karya ini menggunakan tipe dramatik dan bertema keprihatinan terhadap pergeseran nilai dari ritual Marpangir. Pijakan gerak menggunakan gerak Tor-tor yang ada di Kabupaten Mandailing Natal dan memilih gerakan yang sesuai kemudian dikembangkan agar pesan dan maknanya tersampaikan. Properti yang digunakan yaitu Parompa Sadun (Kain khas Mandailing Natal).
\end{abstract}

Kata Kunci: marpangir, budaya, kebersamaan, keprihatinan.

\begin{abstract}
People of Mandailing Natal have a tradition called Marpangir which was done by the ancestors in the ancient time. It is an activity of self-cleaning as a form of welcoming the holy month of Ramadhan. This tradition has several values such as cultural, ethical, religious and social values. Along with the world's development, this ritual has had changes in terms of the way it is done and the ingredients used. Concerns have been raised by researchers regarding the differences of values that appear among the young generations nowadays, which then leads to individualist personnels. These phenomena are interpreted and expressed through publications related. Looking back on the old days, young generations in Mandailing Natal had a strong sense of togetherness and created a saying "Sa Pangambe Sa Panaili". This work of art applies the dramatic type and focuses on the changes of values of Marpangir ritual. The stepping stones are movements of Tor-tor that is available in Mandailing Natal in which they are chosen and developed to suit the message and meaning meant to be delivered. The property used is Parompa Sadun the traditional cloth of Mandailing Natal.
\end{abstract}

Keywords: marpangir, cultural, togetherness, concerns.

\section{PENDAHULUAN}

Adat istiadat daerah Mandailing sangat erat dengan kebiasaan-kebiasan yang dilakukan para nenek moyang. Sebelum Islam masuk ke Mandaling Natal, agama yang di anut adalah agama Hindu-Budha. Pada awal 80-an masyarakat Mandailing sudah menganut agama Islam. Hindu-Budha adalah agama yang memiliki tradisi mandi menggunakan bahan-bahan sesajen. Setelah Islam masuk, tradisi ini tetap dilakukan tetapi tujuannya sudah berbeda. Banyak kebiasaankebiasaan yang dilakukan para leluhur yang sampai sekarang masih dilakukan oleh masyarakat itu seperti
Marpangir. Menurut Bapak Efendi (2017) "Marpangir adalah kegiatan berbentuk kebersihan yang dilakukan Muslim-Muslimah dalam rangka menyambut bulan suci Ramadhan sebagai rasa syukur masih diberi umur panjang dan rasa gembira atas kehadiran bulan suci Ramadhan". Marpangir sebagai wujud bentuk rasa syukur kepada Allah karena masih diberi umur untuk merasakan bulan suci Ramadhan, dimana masyarakat sangat bergembira menyambut bulan itu dengan cara membersihkan diri, membersihkan halaman, menyiapkan bahan makanan, dan lain-lain. Marpangir ini termasuk dalam membersihkan diri dengan 
Gorga : Jurnal Seni Rupa

Volume 10 Nomor 02 Juli-Desember 2021

p-ISSN: 2301-5942 | e-ISSN: 2580-2380

menggunakan bahan-bahan yang menimbulkan bau harum. Bapak Muslim (2017) menyebutkan Marpangir ini sesuai dengan hadist Nabi Muhammad SAW, yang berbunyi:

$$
\text { من فرح بد خول رمضان حرم الله جسده على النيران }
$$

Artinya: "Siapa yang bergembira dengan masuknya bulan Ramadhan, Allah akan mengharamkan jasadnya masuk neraka."

Sesuai dengan hadist di atas, dalam menyambut bulan suci Ramadhan harus lah bergembira salah satu nya dengan cara Marpangir. Hukum Marpangir dalam agama Islam adalah Sunnah.

Marpangir dulu adalah bagian dari budaya karena menggunakan bahan-bahan tradisional seperti kelapa, tapak leman, pandan, nilam, jeruk purut dan abelu kemudian direbus dengan santan ditunggu beberapa hari hingga mengeluarkan bau harum. Lalu sehari sebelum bulan suci Ramadhan anak-anak, muda-mudi dan orang tua beramai-ramai pergi ke sungai (karena zaman dulu belum ada kamar mandi) dimana antara laki-laki dan perempuan mandi secara terpisah untuk melakukan kegiatan mandi menggunakan Pangir. Penggunaan Pangir menurut masyarakat setempat agar aroma wangi tercium jikala masyarakat bertemu saat Shalat Tarawih. Jadi masyarakat nyaman melaksanakan Shalat Tarawih karena di sekelilingnya banyak aroma wangi tersebut.

Seiring perkembangan zaman, terjadi pergeseran nilai pada ritual Marpangir. "Pergeseran merupakan peralihan, perpindahan, pergantian.” (Hasan, 1990: 361) Pergeseran yang pengkarya maksud adalah perubahan yang terjadi dari hal lama menjadi hal yang baru. Hal ini berkaitan dengan perubahan nilai dari Marpangir itu sendiri termasuk didalamnya nilai budaya, nilai sosial, nilai agama dan nilai etika. "Sesuatu dianggap bernilai apabila arah dan pilihan ditujukan pada yang baik, yang menarik dan yang dibolehkan, karena ada manfaatnya bagi manusia dan inilah yang diinginkan oleh manusia dalam hidup bermasyarakat." Marpangir di zaman dahulu memiliki nilai yang baik, terlihat dari sifat bergotong-royong dalam mengumpulkan bahan Pangir, beramai-ramai pergi kesungai untuk mandi bersama-sama tetapi tidak dalam satu wadah selain itu fungsi dari Marpangir itu sendiri adalah bergembira menyambut bulan suci Ramadhan. Marpangir termasuk salah satu dari bagian budaya. "Nilai budaya adalah hasil pengalaman hidup yang berlangsung dalam kurun waktu yang lama, sehingga menjadi kebiasaan yang berpola." Namun dari realita sekarang yang pengkarya lihat Marpangir ini lebih identik untuk hiburan dan rekreasi saja dimana masyarakat Mandailing Natal saat ini menyempatkan untuk berpergian jauh dari tempat tinggal untuk melakukan Marpangir ke tempat-tempat wisata yang berhubungan dengan sungai dan menyiapkan makanan yang diperlukan diperjalanan serta di tempat wisata tersebut dan ini dilakukan bergabung antara laki-laki dan perempuan.

Muda-mudi melakukan Marpangir secara bersamasama di sungai tertentu dan banyak yang lebih memilih berpergian dengan teman dibanding menyambut bulan suci Ramadhan dengan keluarga. Karena tidak sedikit juga yang bepergian ke tempat wisata namun tidak melakukan kegiatan Marpangir, hanya untuk rekreasi dan hiburan.

Etika adalah ilmu tentang apa yang baik dan apa yang buruk dan tentang hak dan kewajiban moral (akhlak). Kegiatan Marpangir sekarang ini mengalami pergeseran etika yang mana banyak muda-mudi tidak menjaga aurat seperti mandi memakai pakaian yang tidak menutup aurat di tempat ramai dan bukan muhrimnya. Merujuk pada ajaran Islam hal ini hukumnya adalah Haram karena Marpangir dilaksanakan dengan menggabungkan yang tidak muhrim. Ini tidak menutup kemungkinan terjadinya hal-hal yang tidak diinginkan berakibat pada rusaknya moral generasi muda.

Berdasarkan fenomena diatas pengkarya terinspirasi untuk menciptakan karya seni tari yang menginterpretasikan pergerseran nilai pada Marpangir. Tujuan kegiatan Marpangir di laksanakan sudah tidak sesuai dengan yang sebenarnya. Ritual Marpangir dilakukan di sungai tetapi menggabungkan antara lakilaki dan perempuan. Muda-mudi tidak menjaga aurat. Kemudian Pangir sudah banyak dilupakan atau sama sekali tidak diketahui oleh muda-mudi.

Pengkarya merasa prihatin atas fenomena diatas dan merasa tergugah untuk bisa mengkritisi masalah yang tengah terjadi pada muda-mudi, dengan harapan dapat menggerakkan hati mereka untuk bisa menyadari dan memahami bahwa mandi dalam satu tempat dengan lawan jenis itu salah. Keprihatinan ini diekspresikankan dalam bentuk karya seni tari yang merupakan salah satu media komunikasi untuk mengungkapkan rasa prihatin terhadap fenomena yang ada di kehidupan masyarakat dan nilai-nilai yang mulai bergeser. Ketertarikan ini didasari oleh pengkarya adalah putri asli Minang yang sudah lama berdomisili di Mandailing Natal yang mana Minang memiliki semboyan "Dima bumi dipijak, di situ langik di junjuang". Hal inilah yang pengkarya aplikasikan 
dalam sebah karya seni sebagai sumbangsih dan pesan terhadap masyarakat di Mandailing Natal. Selain itu, pengkarya ingin mengetahui sejarah tentang Marpangir dan melihat realita yang terjadi saat ini terkait dengan pergeseran nilai dari Marpangir yang dilakukan muda-mudi. Hal lain yang memotivasi yakni pengkarya sebagai pendidik di MTsN 2 Mandailing Natal, merasa berkewajiban untuk memberikan pendidikan pada generasi penerus lewat sentuhan seni dan karya yang diciptakan memberikan pesan/nilai positif terhadap fenomena diatas. Demikian juga hasil tesis/laporan ini pengkarya berharap memberikan informasi yang positif tentang eksistensi budaya Marpangir pada masa lampau di daerah Mandailing Natal.

Karya ini diwujudkan menjadi sebuah karya tari kontemporer yang diekspresikan dengan tema literer dan tipe dramatik. Dalam perwujudannya pengkarya menggunakan 16 orang penari dan tentunya diperkuat oleh musik yang dipercayakan kepada Jumaidil Firdaus, S. Sn sebagai komposernya. Untuk musik ini pengkarya berharap adanya kolaborasi musik dari Mandailing Natal dengan tujuan adanya sentuhan budaya Mandailing yang tentunya tidak terlepas dari garapan musik baru yang memperkuat ide dan gagasan pengkarya.

Karya ini ditampilkan di tempat riset yang pengkarya lakukan dari fenomena budaya ini terjadi dan memilih ruang outdoor untuk penampilan yang tidak terlepas dari ilmu komposisi dan sentuhan artistik lainnya.

Berdasarkan latar belakang dan fenomena diatas maka dapat diambil kesimpulan untuk dijadikan rumusan penciptaan. Rumusan penciptaan adalah Bagaimana menciptakan karya tari berbasis riset yang menginterpretasikan tentang keprihatinan terhadap pergeseran nilai dari Marpangir?

Dalam menciptakan karya tari tentulah tidak terlepas dari tujuan dan manfaat. Adapun tujuan penciptaan karya tari "Sa Pangambe Sa Panaili" ini adalah untuk mendapatkan pemahaman mendalam tentang Marpangir di Mandailing Natal. Untuk mengetahui pergeseran nilai yang terjadi pada prosesi Mapangir. Untuk mewujudkan pergeseran nilai yang terjadi pada prosesi Marpangir ke bentuk tari.

Sedangkan manfaat dari penciptaan karya ini adalah, bagi koreografer dapat mengenal dan memahami lebih dalam lagi tentang ritual Marpangir di Mandailing Natal dan dapat mengimplementasikan teori, konsep dan metode penciptaan tari serta mengembangkan ide dan gagasan melalui kreativitas seni menjadi sebuah
Gorga : Jurnal Seni Rupa

Volume 10 Nomor 02 Juli-Desember 2021 p-ISSN: 2301-5942 | e-ISSN: 2580-2380

karya tari yang inovatif. Bagi dunia akademik adalah sebagai informasi untuk insan akademik tentang tahapan ritual Marpangir yang sesungguhnya. Bagi masyarakat dapat memberikan informasi kepada masyarakat mengenai budaya Marpangir yang memiliki nilai social dan memberikan pesan dan nilai positif pada masyarakat luas dari karya tari "Sa Pangambe Sa Panail”.

\section{KAJIAN TEORI}

\section{Sangkut Dak Menyauh}

Karya tari "Sangkut Dak Menyauh" garapan Suaida pada tahun 2020 terinspirasi dari Tradisi Bekarang yang menurut kepercayaan masyarakat setempat pada dahulunya di Danau Arang-arang ada makhluk disebut transplajo (sebuah batang kayu bulian rubuh kedalam danau). Sejak transplajo ada di sungai tersebut, ikanikan tidak pernah ada habisnya karena pengulu Pinge (orang yang dituakan) memuja makhluk-makhluk halus ikan-ikan tersebut terkumpul disuatu tempat dan masyarakat mudah untuk menangkapnya. Bekarang menjadi salah satu tradisi masyarakat Muaro Jambi yang harus dilestarikan secara turun-temurun. Seiring berkembangnya zaman tradisi ini mulai mengalami perubahan, karena ikan yang didapat mulai berkurang. Ini disebabkan karena faktor cara penangkapan ikan yang sudah berbeda, seperti sentruman ikan, memakai bahan-bahan kimia beracun dan peledak ikan. Tradisi Bekarang mulai mengalami perubahan dan memiliki dampak terhadap nilai sosial pada masyarakat seperti memudarnya kebersamaan, berkurangnya silaturrahim antar warga, lebih mementingkan diri sendiri, merosotnya nilai moral, egois, materialism, sikap dan perilaku negative serta berkurangnya tradisi setempat.

Fenomena yang diambil memiliki persamaan dengan karya tarri "Sa Pangambe Sa Panaili" yaitu berkurangnya nilai sosial, tetapi karya "Sa Pangambe Sa Panaili" ini lebih ke nilai sosial antar muda-mudi yang sudah mulai berkurang. Penggarapan karya tentu berbeda dengan karya tari "Sangkut Dak Menyauh" yang mana karya ini menggarap berbagai ekspresi dengan menggunakan simbol-simbol dari sifat sentruman dan keterjeratan atau keterperangkapan. Sedangkan karya tari "Sa Pangambe Sa Panaili" menggarap berbagai ekspresi personal pengkarya yang melihat perubahan nilai sosial antar muda-mudi dengan menggunakan simbol dari sifat ketidak pedulian, individual dan kegelisahan.

\section{METODE PENELITIAN}

\section{Observasi Data Lapangan \\ 1). Ritual Marpangir}


Dalam menyambut bulan Ramadan, yang dikenal umat Islam sebagai bulan yang suci dan penuh berkah, tentunya terdapat serangkaian kegiatan yang rutin secara turun temurun dilaksanakan oleh sebagian besar masyarakat Indonesia, untuk menyambutnya. Satu di antaranya yaitu mandi bunga atau sering disebut Marpangir. Marpangir biasanya dilaksanakan satu hari sebelum puasa, sebagian masyarakat mengartikan kegiatan ini sebagai proses menyucikan diri menyambut bulan yang suci.

Marpangir adalah kegiatan mandi dengan cara tradisional dengan tidak menggunakan wewangian dari sabun mandi atau sabun cair. Melainkan dari paket dedaunan dan rempah yang disebut Pangir. Paket Pangir terdiri dari daun pandan, daun serai, bunga mawar, kenanga, jeruk purut, daun limau, akar wangi, dan bunga pinang. Jika sedang mudah ditemukan, terkadang ada juga yang menambahkannya dengan akar kautsar dan embelu. Bahkan ada yang menyebutkan yang terpenting ada tujuh macam dedaunan dan rempah di dalamnya. Bahan bakunya pun banyak yang menjual dengan harga yang sangat terjangkau. Pasar-pasar tradisional banyak menjual ini dan hanya ada saat menjelang bulan Ramadhan. Cara membuat pangir yaitu dengan merebus pangir. Setelah itu, air rebusannya digunakan untuk mandi.

Biasanya Marpangir dilakukan sehari sebelum hari Ramadan dan dilakukan beramai-ramai di tempat pemandian. Untuk melakukan tradisi ini, biasanya sekolah diliburkan sehari sebelum puasa. Sehingga masyarakat berbondong-bondong pergi ke pemandian untuk Marpangir bersama. Meski sebenarnya tradisi ini juga bisa dilakukan sendiri di rumah. Tradisi mandi diketahui adalah leburan tradisi umat Hindu sebelum Islam masuk ke Indonesia. Terutama masyarakat Hindu Kuno di Sumatera Utara.

Setelah Islam masuk, awalnya Marpangir hanya dilakukan oleh masyarakat Batak Muslim Suku Mandailing Natal di rumah masing-masing atau beramai-ramai ke tempat pemandian dengan aliran sungai. Tradisi Marpangir dipercaya untuk menghapus dosa. Meski begitu seiring berjalannya ajaran Islam, marpangir dilakukan lebih kepada antusiasme masyarakat menyambut bulan suci Ramadan. Dengan membuat badan jadi lebih wangi dan bersih, dipercaya akan memperlancar pelaksanaan ibadah puasa terutama saat melaksanakan shalat Tarawih, karena wewangian memberi rasa nyaman dan sejuk.
Gorga : Jurnal Seni Rupa

Volume 10 Nomor 02 Juli-Desember 2021 p-ISSN: 2301-5942 | e-ISSN: 2580-2380

\section{Konsep Garapan}

Konsep garapan ini memuat tentang apa yang akan diciptakan, apa yang akan diekspresikan, apa yang akan dicapai serta media dan teknik apa yang digunakan. Hal ini bertujuan untuk pematangan dan pemantapan unsurunsur konsep yang akan diwujudkan. Konsep garapan ini juga memaparkan perancangan visual yang akan diwujudkan dan diekspresikan.'Ide garapan memuat penjelasan padat tentang konsep atau ide kreativitas untuk mengekspresikan isi ke dalam wujud seni-teater, tari, musik, film, kriya, rupa, dan lain-lain" (Dharsono, 2016: 40).

Konsep penciptaan karya dengan judul " "Sa Pangambe Sa Panaili'"' pengkarya terinspirasi dari fenomena sosial dari Ritual Marpangir yang berupa pergesaran nilai dari ritual Marpangir yang ada di kabupaten Mandailing Natal yang digarap dengan bentuk ekspresi personal.

Keinginan pengkarya dalam mengangkat ide yang bersumber dari pengalaman pribadi ini karena adanya persoalan perbedaan prilaku muda-mudi yang pada zaman dahulu saat melakukan Ritual Marpangir ini di sungai sebab tidak ada kamar mandi seperti sekarang. Namun kebanyakan muda-mudi lebih memilih dengan berbondong-bondong melakukan ritual ini ke sungaisungai tertentu yang jauh dari tempat tinggal mereka, kemudian mereka mandi dalam satu wadah yang sama. Padahal Mandailing Natal memiliki semboyan "Negeri Beradat, Taat Beribadat". Justru prilaku ini tidak mencerminkan semboyan yang telah ada di Mandailing Natal saat ini.

Kemudian muncul sebuah ide dan gagasan pengkarya yang menuangkan ide tersebut ke dalam bentuk komposisi tari yang memfokuskan kepada sebuah nilai positif dan sosial masyarakat tentang proses Ritual Marpangir pada zaman dahulu, baik melalui aktivitas muda-mudi dari cara mengumpulkan alat dan bahan secara gotong royong, saling bahu-membahu membuat bahan-bahan menjadi Pangir hingga bersama-sama pergi ke sungai dan mandi ditempat pemandian masing-masing.

Berdasarkan pengamatan pengkarya terhadap persoalan perubahan prilaku muda-mudi ini muncul kesadaran bahwa sebuah budaya harus tetap dilestarikan karena hal tersebut merupakan kekayaan dan khas dari tempat tersebut. Setiap keunikan dari daerah tersebut harus tetap dijaga etika dan estetikanya.

Karya ini diwujudkan menjadi karya baru dengan bentuk ungkapan personal, sebab karya ini nantinya 
Gorga : Jurnal Seni Rupa

Volume 10 Nomor 02 Juli-Desember 2021

p-ISSN: 2301-5942 | e-ISSN: 2580-2380

akan digarap berdasarkan interpretasi terhadap pengalaman pribadi dan cara pandang pengkarya melihat perubahan prilaku muda-mudi dalam proses Ritual Marpangir. Adanya nilai dan pesan yang ingin disampaikan dalam karya ini, yakni bahwa perbedaan alat dan bahan dalam Ritual Marpangir tentu saja berbeda, namun cara melakukan tidak boleh berubah.

\section{HASIL DAN PEMBAHASA}

\section{Hasil}

Perancangan Karya. Karya I: Mengekpresikan Kabupaten Mandailing Natal yang memiliki semboyan "Negeri Beradat, Taat Beribadat" dimana akan menampilkan tari Tor-tor Naposo Nauli Bulung (tari muda-mudi yang ada dalam prosesi adat pernikahan) yang syair dari tarian ini berisi tentang pesan orang tua kepada muda-mudi.

Karya II: Bagia satu: Menginterpretasikan syair dan mengekspresikan nilai budaya dari Marpangir yang sudah mulai ditinggalkan oleh muda-mudi. Bagian dua: Menggambarkan keprihatinan dan kegelisahan terhadap fenomena pergeseran nilai dari Marpangir. Bagian tiga: Menginterpretasikan terciptanya nilai-nilai budaya yang diharapkan.

Judul yang baik untuk sebuah karya seni adalah judul yang berikan bekal bagi penonton untuk segera menangkap ruang lingkup masalah yang menjadi latar belakang maupun pesan dari karya tersebut. Karya ini diberi judul " "Sa Pangambe Sa Panaili”.

"Sa Pangambe Sa Panaili” dalam bahasa Mandailing merupakan sebuah ungkapan yang mempunyai makna ketika dua orang atau lebih jalan bersama maka ayunan tangan selalu bersamaan dan mata juga melihat objek yang sama. Dalam ritual Marpangir pada zaman dahulu dilakukan secara bersama-sama dan bergotong royong, sikap ini adalah gambaran dari perilaku mudamudi. Berbeda halnya dengan zaman sekarang dimana muda-mudi kurang peduli dengan sesamea, lebih individual tanpa ada rasa empati satu sama lain. Dalam menginterpretasikan fenomena perbedaan budaya Marpangir yang dilakukan muda-mudi tersebut sebagai wujud ekspresi personal.

Tema yang digunakan dalam garapan karya tari ini yaitu "literer", dalam buku Ketika Cahaya Merah Memudar, sebuah kritik tari dijelaskan bahwa tema literer ialah komposisi tari yang digarap dengan tujuan untuk menyampaikan pesan-pesan seperti: cerita, pengalaman pribadi, interpretasi Karya sastra, dongeng cerita rakya sejarah dan sebagainya (Murgiyanto, 1993: 43). Dalam karya " "Sa Pangambe Sa Panaili”" ini pengkarya mengekspresikan dan menginterpretasikan keprihatinan dari sebuah fenomenana sosial dalam ritual Marpangir yang mana pada saat ini banyak perbedaan dan perubahan perilaku pada muda-mudi.

Tipe tari yang digunakan dalam penggarapan karya " $S a$ Pangambe Sa Panaili” yakni tipe tari Dramatik. Tipe dramatik mengandung arti bahwa gagasan yang diungkapkan sangat kuat dan penuh daya pikat, dinamis, penuh ketegangan, dan dimungkinkan melibatkan konflik antara seorang dengan dirinya atau dengan orang lain. Tipe tari ini lebih memusatkan perhatian pada sebuah kejadian atau suasana dan tidak menggelarkan cerita secara naratif. Konsep tari "Sa Pangambe Sa Panaili" memusatkan pada suasana yang tidak menguraikan alur cerita. Bentuk suasana yang ditampilkan dalam karya ini dimulai dari menggambarkan nilai budaya melalui tari Tor-tor Naposo Nauli Bulung. Kemudian suasana yang menggambarkan pergeseran nilai yang dilakukan muda-mudi dalam melaksanakan ritual Marpangir dimana muda-mudi mandi dalam satu wadah yang sama dan selanjutnya suasana keprihatinan yang pengkarya rasakan dalam melihat fenomena tersebut.

Gerak merupakan peralihan atau kedudukan, baik hanya sekali maupun berkali-kali. Karya tari merupakan sebuah seni komunikatif yang menggunakan gerak sebagai materinya, gerak dalam sebuah karya tari merupakan elemen utama yang dilahirkan melalui tubuh penari. Gerak dalam tari berbeda dengan gerak sehari-hari, karena gerak dalam sebuah tari terbentuk melalui perombakan, perpindahan dan stilisasi dari yang wantah menjadi bentuk karya seni (Hadi, 2003: 3). Karya tari yang diciptakan melalui gerak dapat berbicara dengan kekuatan dan perasaan yang diinginkan oleh seorang pengkarya. Pijakan gerak yang pengkarya gunakan dalam penggarapan karya "Sa Pangambe Sa Panaili" yakni dari laku itu sendiri dan gerak Tor-tor Mandailing yang di wujudkan dalam bentuk inovasi yang disesuaikan dengan kebutuhan suatu gambaran dari karya tersebut. Pijakan gerak yang digunakan dalam karya ini adalah gerak kontemporer. Pemilihan pijakan gerakan disesuaikan atas pertimbangkan sinkron konsep karya dengan konsep gerakan.

Penari adalah mereka yang melakukan suatu pergerakan yang dapat mewujudkan keinginan seorang koreografer untuk dapat menyampaikan suatu ungkapan perasaan. Dalam karya "Sa Pangambe Sa Panaili” diekspresikan dengan 16 orang penari, lima orang penari perempuan dan lima orang penari laki-laki yang memiliki dasar gerak dan ketubuhan yang sama 


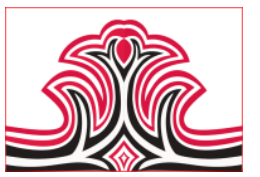

untuk pencapaian ide dan perwujudan karya yang menggambarkan fenomena pergerseran nilai dari ritual Marpangir. Kemudian enam penari tari Tor-tor Naposo Nauli Bulung yang terdari dari tiga pangayapi (penari laki-laki) dan tiga panortor (penari perempuan) yang menggambarkan adat istiadat Mandailing dengan menampilkan tarian muda-mudi. Alasan pengkarya memakai sepuluh penari untuk menggambarkan mudamudi yang melakukan ritual Marpangir karena pengkarya menggambarkan nilai sosial yaitu gotong royong dan kerjasama. Kemudian memakai enam penari untuk tarian tradisional Mandailing yaitu Tortor Naposo Nauli Bulung yang menggambarkan nilainilai budaya yang ada di Mandailing Natal. Pengkarya mempertimbangkan memilih penari berdasarkan ukuran dan postur tubuh, sehingga pengkarya memilih penari yang rata-rata hampir sama memiliki tinggi dan postur tubuhnya. Ini sangat menguntungkan dalam segi visual dan estetis pertunjukan.

Tata rias dan busana merupakan salah satu elemen tari yang sangat mendukung suasana pada tiap penggarapan adegan. Menurut Daryusti, "Tata rias merupakan pentaan wajah penari mencakup polesan muka, peronaan pipi, pewarnaan kelopak mata, pembetukan alis dan pewarnaan bibir. Tata busana merupakan penataan busana penari yang sesuai dengan tuntutan tarian" (Sari, 2020: 35). Karya "Sa Pangambe Sa Panaili" menggunakan tata rias cantik sehari-hari atau biasa dikenal dengan istilah make up minimalis sebagai pendukung karakter muda-mudi dan kebutuhan sebuah pertunjukan. Memperlihatkan kecantikan yang dimiliki oleh perempuan desa secara alami.

Busana yang digunakan pada bagian pertama karya I pada pertunjukan ini adalah busana khas Mandailing yang terdiri dari baju kurung hitam, songket merah, Parompa sadun (Ulos khas Mandailing) dan selempang Ulos. Selanjutnya untuk penari laki-laki menggunakan busana kemeja putih, celana keper hitam, peci hitam, songket merah dan dibalut dengan Parompa sadun.
Gorga : Jurnal Seni Rupa

Volume 10 Nomor 02 Juli-Desember 2021 p-ISSN: 2301-5942 | e-ISSN: 2580-2380

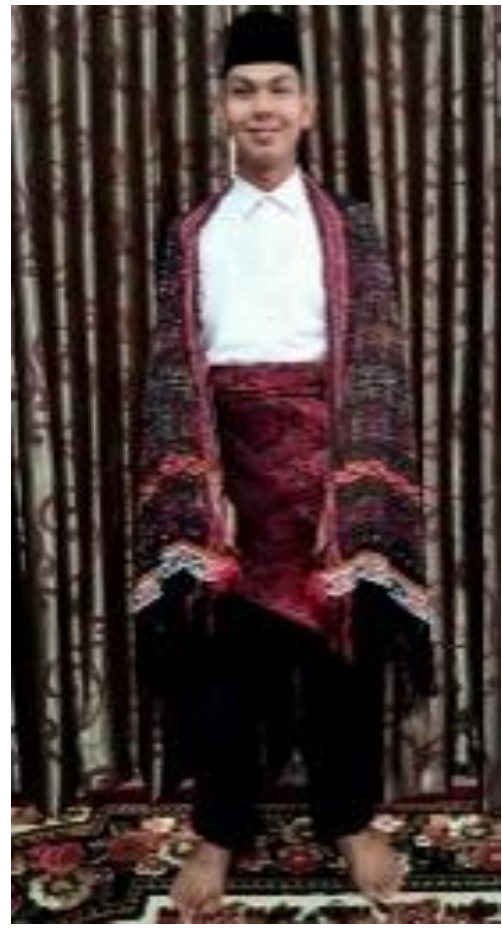

Gambar 1.

Busana Khas Mandailing (Sugianto, 2021)

Penari perempuan menggunakan aksesoris gaja meong (kalung khas Mandailing), Jagar adat Mandailing (hiasan di kepala), sanggul dan Obi (ikat pinggang).

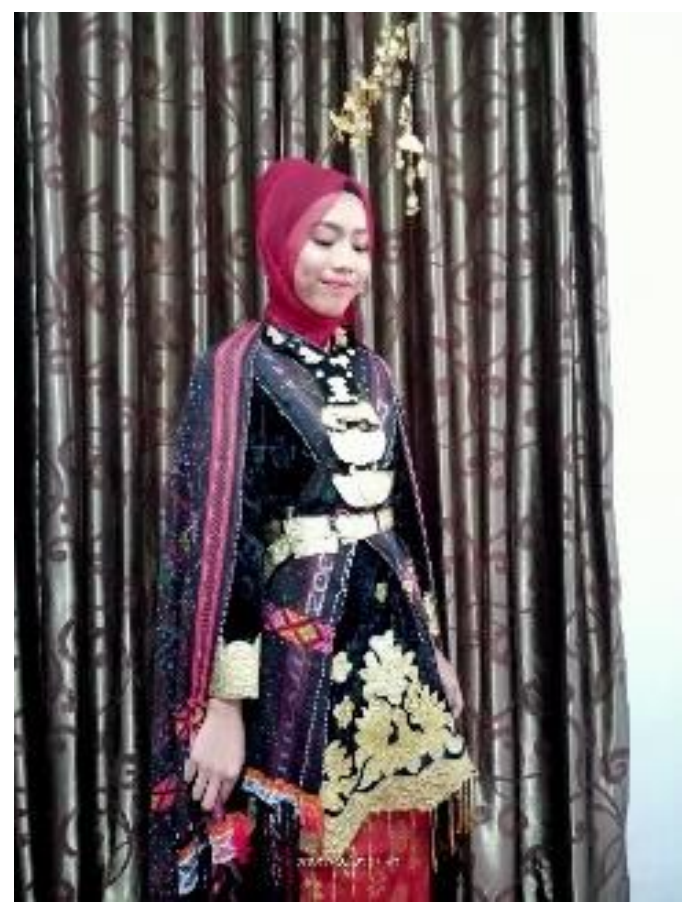

Gambar 2.

Aksesoris tari tradisi Tor-tor Naposo Nauli Bulung (Sugianto, 2021) 


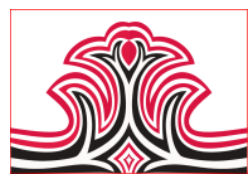

Pada karya II, bagian satu dan dua pada pertunjukan ini penari perempuan menggunakan baju kurung berwarna abu-abu dan memakai celana berwarna hitam yang menyimbolkan suasana suram dari pergeseran nilai ritual Marpangir yang dilakukan oleh muda-mudi. Kemudian penari laki-laki menggunakan baju berlengan pendek warna hitam dan celana pendek warna abu-abu. Pemilihan warna abu-abu diinterpretasikan cara berfikir muda-mudi yang pendek, tidak berpendirian dan mudah dipengaruhi.

Busana perempuan yang digunakan pada bagian tiga penari laki-laki memakai baju berlengan panjang berwarna merah dengan celana panjang berwarna hitam. Kemudian penari perempuan memakai baju kurung berwarna merah dan rok kembang warna hitam.. Pemilihan warna merah pada busana penari adalah untuk menyimbolkan bahwa muda-mudi itu kuat, energik, cepat, berani dan positif yang mana muda-mudi pada pertunjukan ini sudah mulai mendengar nasihat-nasihat yang di sampaikan oleh orang tua dan memiliki rasa kebersamaan yang tinggi. Penggunaan busana pada bagian ini terinspirasi dari pakaian yang sering digunakan muda-mudi pada zaman sekarang.

Hidajat menjelaskan dalam bukunya yang berjudul Pengantar Teori Dan Praktek Menyusun Tari Bagi Guru, Setting ialah hiasan untuk memberikan kejelasan pada penonton agar lebih mudah membayangkan sesuatu yang disajikan. Properti adalah istilah dalam bahasa Inggris yang berarti alat-alat pertunjukan. Memiliki dua tafsiran yakni alat sebagai set dan alat sebagai alat bantu berekspresi. (Hidajat, 2008: 70). Karya "Sa Pangambe Sa Panaili" menggunakan setting yang sederhana. Tempat pertunjukan karya ini sudah memiliki setting yang sesuai dengan konsep pengkarya. Kemudian menggunakan properti Parompa sadun (Ulos khas Mandailing) yang menyimbolkan tentang adat Mandailing Natal karena Parompa sadun ini selalu digunakan dalam acara adat. Selanjutnya properti ember dan bakul menggambarkan Marpangir pada zaman dahulu dan pada zaman sekarang ini sudah mulai ditinggalkan.
Gorga : Jurnal Seni Rupa

Volume 10 Nomor 02 Juli-Desember 2021 p-ISSN: 2301-5942 | e-ISSN: 2580-2380

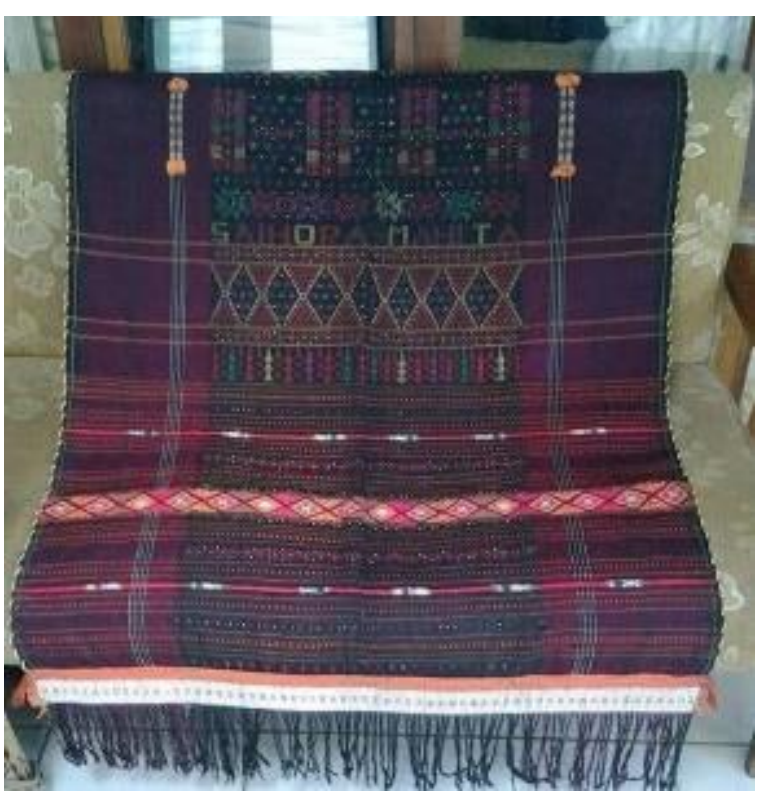

Gambar 3.

Properti Parompa Sadun (Sugianto, 2021)

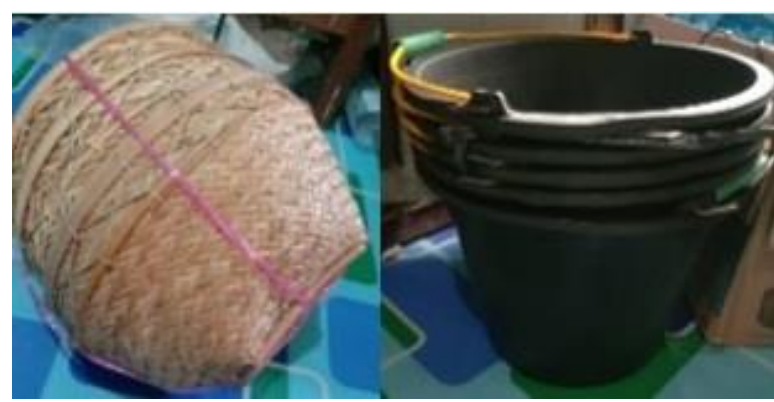

Gambar 4

Properti Bakul dan Ember

(Sugianto, 2021)

Musik adalah partner tari, sebagai penegasan gerak, dan ilustrasi, dengan demikian tari harus mendapatkan musik yang dapat memberi dukungan dalam garapan tari tersebut. Karya tari "Sa Pangambe Sa Panaili" menggunakan instrumen musik seperti gordang sambilan, seruling, gong, talempong (eneng-eneng) dan vokal dengan pijakan syair-syair yang bertemakan muda-mudi yang merupakan salah satu musik khas yang berasal dari Mandailing Natal dan memungkinkan untuk menghadirkan suasana yang di inginkan.

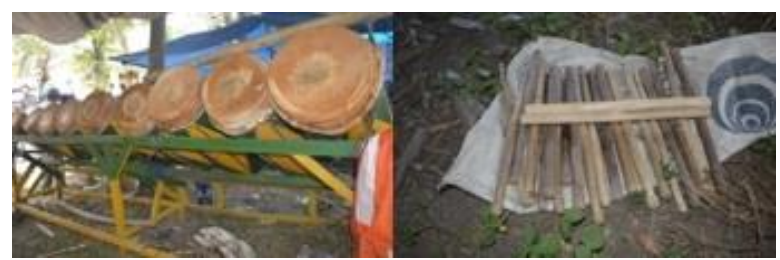

Gambar 5.

Alat Musik Gordang Sambilan dan (Sugianto, 2021) 


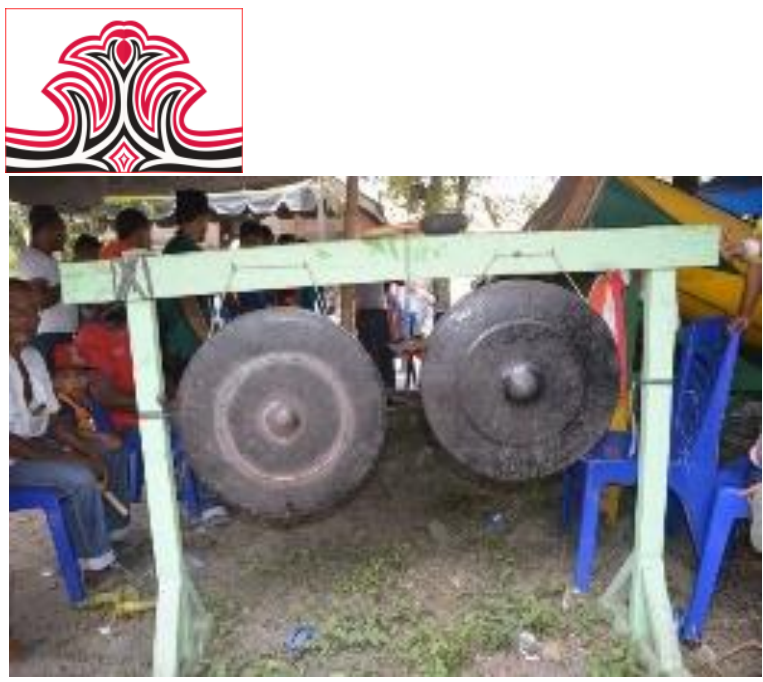

Gambar 6.

Alat Musik Gong. Sabajior (Sugianto, 2021)

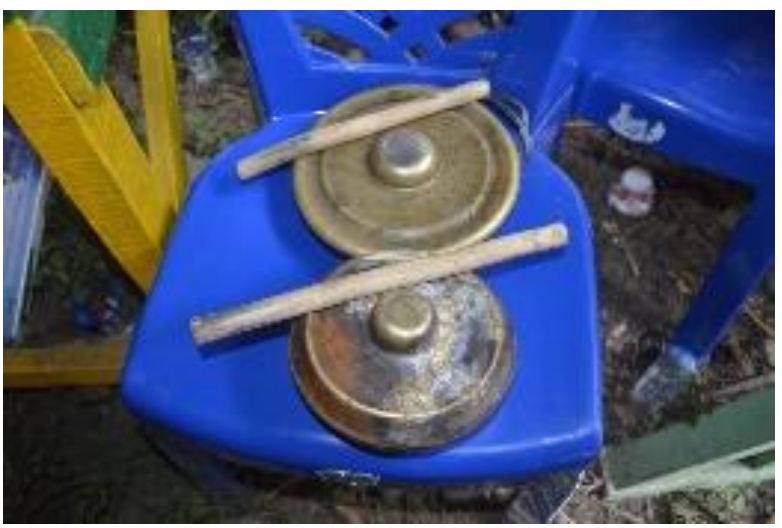

Gambar 7.

Alat Musik Talempong (Eneng-eneng) (Sugianto, 2021)

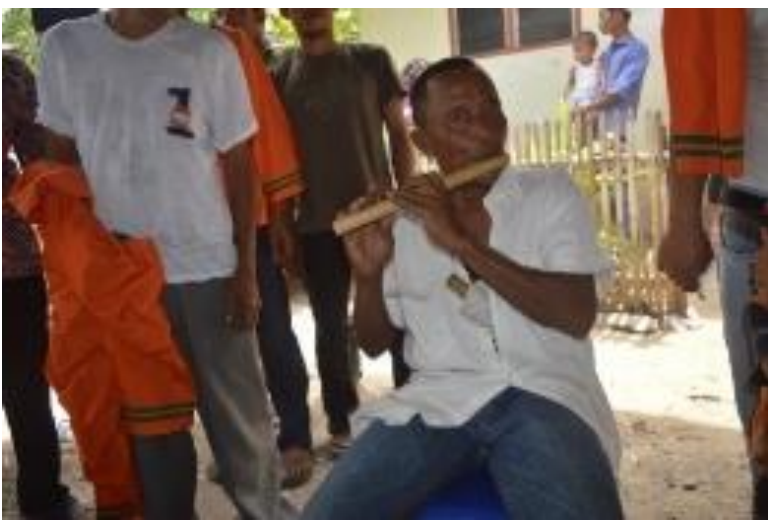

Gambar 8.

Alat Musik Seruling Bambu (Sugianto, 2021)

Lirik Vocal Syair Tari

Tor-tor Naposo Nauli Bulung

Patik dohot uhum (Aturan dan hokum)

Ugari dohot ujarujaran (Kesepakatan dan kebiasaan)

Denggan hita markoum (Baik-baiklah dalam bersaudara)

Asa totop mar siargaan (Agar tetap saling menghargai)

Hombar adat dohot ibadat (Adat dan ibadat berdampingan)
Gorga : Jurnal Seni Rupa

Volume 10 Nomor 02 Juli-Desember 2021

p-ISSN: 2301-5942 | e-ISSN: 2580-2380

Manogu hita tu hapadean (Memandu kita kepada hal yang lebih baik)

Anso denggan marmasarakat (Agar baik

bermasyarakat)

Paihut poda ni ompuna robian (Mengikuti nasehat leluhur)

Basa lungun gogo alap ari (Rasa rindu yang kuat menjemput hari)

Ulang lupa mandok santabi (Jangan lupa minta maaf)

Nabaun mangkatai (Yang pandai berbicara)

Siulaon ni koum di urupi (Sakit saudara diobati)

Hormat Marmora (Hormat kepada mora)

Domu markahanggi (Akrab kepada kahanggi)

Elek muse maranak boru (Mengambil hati kepada anakboru)

Asa malo padomu tahi (Agar pandai menyatukan mufakat)

Salaklak sasingkoru (Se-laklak se-singkoru)

Sasanggar sa ria ria (Se-sanggar se-riaria)

Saanak jana saboru (Se-putra dan se-putri)

Na suang marsada ina (Mirip seperti se-ibu)

Ulang pasala sili (Jangan saling silang)

Songon parkuayam ni ajaran (Seperti rusa sedang menguap)

Muda nada satahi (Bila tidak sepaham)

Hata ni bada na momoan (Akan mudah bertengkar) Muda talaga jadi juluan (Bila hilir jadi hulu)

Ra mai tarinum aek ni parbasuan (Bisa akan terminum air cuci tangan)

Hormat tu ama dohot ina (Hormat kepada ayah dan $\mathrm{ibu)}$

Tarlobi natobang natoras di huta (Utamanya yang dituakan di kampong)

Silehen tutur dohot poda (Yang memberikan pembelajaran)

Na padaohon sagalo mara (Yang menjauhkan dari mara bahaya)

Ulang songon pisang gasgas (Jangan seperti pisang gasgas)

Tabiatna sarat naluas (Tabiatnya sembarangan saja) Mangkatai marmilas-milas (Bicara kasar-kasar)

Gabe halak marholas-holas (Membuat orang marahmarah)

Naposo bulung pagar ni huta (Para pemuda pagar kampong)

Nauli bulung bunga desa (Para pemudi bunga desa) Jagar-jagar ni halak di huta (Hiasan warga kampong) Sioban tua dohot sahala (Membawa berkah dan kemuliaan)

Naposo nauli bulung (Pemuda pemudi)

Panamba ni gogo naso sadia (Menambah kekuatan yang tak seberapa)

Pasigopkon tohap marujung (Mempercepat pekerjaan selesai) 
Anggo talehen tutur poda (Bila kita beri ilmu pengetahuan)

Jago-jago ni si jimat (Jaga-jaga azimat)

Liang batu di tungkolan (Liang batu ditopang)

Dompak so ro nasib malarat (Sebelum datang nasib melarat)

Parsiapkon na dapot di tangan (Persiapkan apa yang bisa diraih)

Tata cahaya digunakan sebagai alat penerangan didalam pertunjukan. Penerangan ini sudah ada sejak dimulainya suatu pertunjukan. Menurut Adirozal, "Penerangan adalah upaya menerangi seluruh pentas, semua pentas mendapat kekuatan cahaya sama. (Sari, 2020: 24). Penerangan dihardirkan untuk mendukung suatu karya secara general dan spotlight. Pencahayaan bagian pertama pada karya I, dominan menggunakan pencahayaan general agar tercipta suasana kampung yang masih alami. Kemudian karya II pada bagian satu masih menggunakan pencahayaan general dan sudah divariasikan dengan pencahayaan spotlight yang menciptakan suasana muda-mudi disungai dan menciptakan sifat individual. Bagian dua menggunakan pencahayaan general berwarna merah yang menciptakan suasana keprihatinan terhadap pergeseran nilai dari Marpangir. Lalu pada bagian ini juga menggunakan pencahayaan spotlight yang terfokus kepada Ungut-ungut yang disyairkan. Bagian tiga menggunakan pencahayaan general yang menciptakan suasana damai.

\section{Pembahasan}

Karya ini dibagi menjadi tiga bagian dan dipertunjukkan selama kurang lebih 40 menit. Bagian pertama lebih kurang 25 menit, bagian kedua lebih kurang 10 menit dan bagian tiga kurang lebih 5 menit. Struktur karya beserta penyajiannya adalah sebagai berikut:

Karya I menampilkan tarian Tor-tor Naposo Nauli Bulung sebagai tari tradisional Mandailing Natal. Tarian ini menginterpretasikan budaya Mandailing Natal yang memiliki makna khusus yaitu nasihat dari orang tua kepada muda-mudi yang selalu menjaga kesopanan terhadap yang lebih tua, menghormati para petuah dan selalu meminta berkah kepada Tuhan. Ragam gerak pada tarian ini sangat sederhana dan memiliki makna disetiap gerakan serta memiliki nama tertentu. Pola lantai segitiga pada tarian ini disebut Dalihan Natolu yang melambangkan kekerabatan. Pesan yang disampaikan adalah dalam menjalani kehidupan muda-mudi dari zaman dahulu sampai saat ini masih berpegang teguh dengan adat dan budaya yang menjunjung tinggi nilai agama, nilai sosial dan nilai etika dalam bermasyarakat.

Karya II pada bagian sati menghadirkan gerakan mudamudi yang menyimbolkan pelestarian budaya pada zaman sekarang yang sudah berubah seperti tidak menjalankan aturan adat dan tidak saling bergotong royong. Ini terlihat dari penggunaan Parompa Sadun sebagai properti yang ditarikan oleh dua orang penari yaitu laki-laki dan perempuan yang sudah tidak semestinya. Parompa Sadun biasanya digunakan dalam adat dan dibalut ketubuh sementara pada adegan ini properti tersebut sudah diayunkan dan menyentuh tanah. Penggunaan properti ini menyimbolkan ketidak pedulian muda-mudi terhadap adat dan budaya yang sudah lahir sejak zaman dahulu. Pada adegan ini juga menggambarkan hilangnya kebersamaan antar mudamudi dan menimbulkan sifat individualisme. Kemudian gerakan pada adegan ini juga menggambarkan kegiatan dari ritual Marpangir pada saat ini yaitu disungai yang mana muda-mudi mandi dalam satu wadah.

Bagian dua, karya ini menginterpretasikan keprihatinan melihat fenomena pergeseran nilai yang dilakukan muda-mudi dalam ritual Marpangir. Kemudian ditampilkan Ungut-ungut (nyanyian kesedihan) yang disyairkan oleh Ompung (kakek) yang menginterpretasikan keprihatinan melihat pergeseran nilai budaya yang dilakukan muda-mudi pada zaman sekarang.

\section{Syair Ungut-Ungut}

Muda eme baya di uta bargot (Kalau padi di Huta Bargor)

Topet di saba baya roba-roba (Tepat di sawah bergoyang-goyang)

Dau ende on jolo baya da utut (Nyanyian lembut ini dulu yang sedih)

Na hancit di baya dibagasan roha (Sungguh sakit di dalam hati)

Ombar adat dohot ibadat (Umbarlah adat dan ibadah) Malogu ita tu hapadean (Berlomba kita ke yang baik) Anso denggan marmasyarakat (Agar bagus bermasyarakat)

Paiut poda ni ompu na robian (Ikutilah nasehat nenek yang dahulu)

Hormat tu ama dot ina le (Hormat ke ayah dan ibu) Tarlobi natobang natoras dihuta (Terlebih yang tua dan dewasa dikampung)

Silehen tutur dohot poda le (Memberi tutur dan nasehat) 
Napadao on sagalo baya (Untuk menjauhkan semua yang buruk)

Ulang songon pisang gasgas (Jangan seperti pisang gasgas)

Tabiat na sarat na luas (Sikap syarat yang luas)

Mangkatai marmilas milas (Tinggi berpanas-panas)

Gabe halak marholas-holas (Kaya orang bermarahmarah)

Naposo bulung pagar ni uta (Pemuda itu pagarnya kampung)

Nauli bulu bunga desa (Pemudi itu bunga desa)

Jagar-jagar ni halak ni huta (Mahkotanya orang kampung)

Sioban tuba dohot sahalak (Membawa racun untuk sendiri)

Syair diatas adalah ungkapan keprihatinan melihat pergeseran nilai budaya sekaligus nasehat kepada muda-mudi agar mematuhi dan mendengarkan nasehat yang diberikan oleh orang tua. Syair ini juga menggambarkan bahwa muda-mudi yang beradat dan beribadat sangat berarti serta dibanggakan bagi masyarakat. Muda-mudi yang beradat dan beribadat adalah tonggak untuk masa depan daerah yang cerah.

Bagian tiga menggambarkan muda-mudi yang sudah mulai mengikuti adat dan budaya Mandailing Natal. Pada bagian akhir pertunjukan karya ini memiliki pesan mengajak muda-mudi untuk kembali mengikuti aturan adat dan nasehat dari nenek moyang.

Anso dapot hamu, hasonangon ni namar-masyarakat. Adat na mangolu on modom marsiingotan,

Di nangot marsipaingot-ingotan.

Sahata sapangandok, sapangambe, sapanaili. Agar kita mendapat kesenangan dalam bermasyarakat. Aturan kehidupan ini harus saling mengingat. Bagi yang hidup saling ingat-mengingatkan. Sebahasa seucapan, selangkah, sevisi.

Karya tari "Sa Pangambe Sa Panaili" memiliki tiga bagian karya dengan suasana yang berbeda. Pada karya I menghadirkan suasana tradisi yang menggambarkan muda-mudi yang sopan dan patuh kepada orang tua. Busana yang digunakan adalah busana khas adat Mandailing dan dibalut Parompa Sadun yang menyimbolkan bahwa muda-mudi menjalani kehidupan dengan aturan, adat dan budaya. Dasar gerak yang digunakan gerak khas Mandailing yaitu Tor-tor yang mengacu pada konsep masing-masing bagian karya. Pada karya ini memakai 6 orang penari diantaranya tiga penari laki-laki (pangayapi) dan tiga penari perempuan (panortor). Karya ini dimulai dari gerakan Tor-tor khas Mandailing yang disetiap geraknya memiliki makna tentang aturan, adat dan budaya.

Karya II pada bagian satu menggambarkan muda-mudi yang mulai acuh tak acuh kepada budaya yang ada. Gerak yang digunakan pada adegan ini adalah gerak kreasi Tor-tor yang sesuai dengan konsep karya. Setelah tari tradisional Mandailing, muncullah satu penari perempuan dan satu penari laki-laki melakukan gerakan dinamis dengan properti Parompa Sadun, menggambarkan muda-mudi yang masih mengikuti adat dan budaya namun sudah mengalami pergeseran. Busana yang digunakan berwarna merah, laki-laki memakai songket merah dan perempuan menggunakan rok songket merah. Kemudian satu penari perempuan mencari posisi untuk melakukan gerakan individual di sambung dengan satu penari laki-laki yang juga melakukan gerakan individual. Pada bagian ini menjelaskan bahwa adat dan budaya di Mandailing Natal sudah mulai ditinggalkan dan mengalami perubahan. Padahal dulu muda-mudi di Mandailing sangat terkenal dengan kebersamaan dalam bersosial. Selanjutnya, enam penari sudah pada posisi disekitar sungai dan melakukan gerakan rampak sementara dua penari mencari posisi dan melakukan gerakan yang berbeda. Gerakan yang dilakukan delapan penari menggambarkan kegiatan mandi bersama-sama di sungai yang diambil dari ritual Marpangir pada saat ini dan menjadi keprihatinan pengkarya. Busana penari perempuan adalah baju kurung warna merah dan rok songket berwarna merah. Kemudian busana laki-laki baju merah, celana hitam dan songket merah. Kemudian satu penari perempuan dan satu penari lakilaki melakukan gerakan yang bebeda dengan keenam penari lainnya yang menggambarkan individualisme yang terjadi pada muda-mudi, ketidak pedulian mudamudi terhadap sesama dan kebersamaan yang sudah mulai hilang.

Suasana yang hadir pada adegan ini memiliki dua suasana yaitu suasana senang dan sedih ini terlihat dari kesenangan muda-mudi mandi disungai secara bersama- sama dan ketidak pedulian muda-mudi terhadap nasehat yang ada pada syair yang dinyanyikan. Busana yang dipakai oleh penari perempuan baju kurung berwarna abu-abu dan celana hitam. Kemudian busana yang digunakan laki-laki baju hitam dan celana abu-abu. Pemilihan warna hitam dan abu-abu menyimbolkan pembaharuan seperti menggunakan budaya modern yang melanggar adat dan budaya. Konsep pada adegan ini perbedaan realitas muda-mudi pada zaman dahulu dan zaman sekarang. 
Gorga : Jurnal Seni Rupa

Volume 10 Nomor 02 Juli-Desember 2021

p-ISSN: 2301-5942 | e-ISSN: 2580-2380

Bagian dua, menghadirkan bentuk abstrak dan suasana sedih untuk menggambarkan keprihatinan terhadap prilaku yang dilakukan muda-mudi saat ini. Pada bagian ini ditampilkan Ungut-Ungut (ratapan yang dinyanyikan) yang berisi kesedihan melihat mudamudi yang sudah tidak mengikuti aturan, adat dan budaya yang telah dilakukan orang tua pada zaman dahulu. Konsep gerakan pada bagian ini adalah abstrak karena menggambarkan suasana kesedihan dan keprihatinan. Karya ini dimulai dari penari satu-persatu masuk ke area melakukan gerakan kontemporer, kemudian penari melakukan gerakan bergantian dan tidak sama yang menggambarkan individualisme, ketidak pedulian dan hilangnya sifat kebersamaan diantara muda-mudi.

Pada bagian ketiga, menggambarkan muda-mudi yang sudah mulai mau mengikuti aturan adat yang ada. Ini terlihat dari penggunaan properti Parompa Sadun yang digunakan oleh penari. Gerakan yang dilakukan penari adalah gerakan dinamis dan mengalir, pijakan geraknya menggunakan gerak Tor-tor. Karya pada bagian ini dimulai dari lima penari laki-laki dan lima penari perempuan secara bergantian masuk ke dalam area kemudian membentuk lingkaran dan melakukan gerakan tor-tor. Selanjutnya membentuk pola V melakukan gerakan dinamis dan mengalir. Lalu pada bagian akhir memiliki pesan yang berisi ajakan kepada muda-mudi agar mengikuti aturan adat yang ada dan nasehat kepada muda-mudi.

Pada awal karya ini tercipta suasana hikmat perkampungan yang tenang didukung oleh musik tradisi dan tari tradisi Mandailing Natal dengan jumlah penari 6 orang diantaranya 3 laki-laki dan 3 perempuan. Kemudian satu penari perempuan dan satu penari laki-laki melakukan gerakan kreasi Tor-tor dengan properti Parompa Sadun yang dililit di tubuh maupun diayunkan kekanan dan kekiri yang menggambarkan muda-mudi masih mengikuti adat dan budaya Mandailing Natal. Satu penari perempuan telah berada di ujung kanan panggung melakukan gerakan kontemporer dan di lanjut dengan satu penari laki-laki berada di belakang menggambarkan individualisme muda-muda pada saat ini. Tiga penari laki-laki dan tiga penari perempuan telah berada di sungai membentuk pola zig-zag disusul dengan satu penari perempuan dan satu penari laki-laki melakukan gerakan kontemporer yang menggambarkan kegiatan Marpangir yang dilakukan muda-mudi pada saat ini. Satu penari lakilaki dan satu penari perempuan melakukan gerakan kontemporer sementara tiga penari laki-laki dan tiga penari perempuan melakukan gerakan dinamis yang menggambarkan mandi disungai secara bersama-sama.
Gerakan mandi disungai ini adalah konsep yang menggambarkan pergeseran nilai dari kegiatan Marpangir yang dilakukan muda-mudi pada saat ini. Satu penari perempuan mengelilingi empat penari lakilaki yang berbentuk diagonal menggambarkan bahwa perempuan pada saat ini sudah mau berbaur dengan laki-laki.

Lima penari laki-laki dan lima penari perempuan masuk ke area melakukan gerakan kontemporer dengan pola lantai zig-zag yang masih menggambarkan mudamudi yang berbaur satu sama lain tidak ada perbedaan diantar laki-laki dan perempuan. Kemudai satu penari laki-laki melakukan gerakan kontemporer, satu penari laki-laki rolling, dua penari laki-laki melakukan gerak duduk, satu penari perempuan berlari secara diagonal disusul satu penari laki-laki, satu penari perempuan berlari menyusul penari laki-laki, disusul bergerak satu penari laki-laki dan satu penari perempuan yang menggambarkan individual, ketidak pedulian dan tidak memiliki sifat kebersamaan, Kemudian masuklah penyair Ungut-Ungut dan satu pemain seruling menuju tengah area, lima penari perempuan dan lima penari laki-laki berdiri menghadap penyair mendengarkan syair-syair yang dilantunkan, lalu sesekali bergerak maju dan mundur. Beberapa penari keluar area untuk mengganti baju disusul penari yang lain.

Lima penari laki-laki dan lima penari perempuan berjalan bergantian masuk ke area dengan membuat pola lingkaran dengan tangan disilangkan ke bahu. Kemudian perlahan duduk melakukan gerakan dinamis secara bersama-sama, lalu berdiri menghadap ke depan melakukan gerakan Tor-tor. Kemudian membuat pola vertikal melakukan gerakan Tor-tor, penari berhadaphadapan. Penari membuat pola V dan kemudian duduk melakukan gerakan dinamis dilanjukan berdiri dan melakukan gerakan tor-tor. Gerakan ini menggambarkan bahwa muda-mudi sudah mulai mengikuti aturan adat dan sudah mau mendengar nasehat-nasehat yang diberikan oleh orang tua. Selanjutnya penari melakukan gerakan rampak yang menggambarkan kebahagiaan dan muda-mudi yang sudah mau mendengarkan nasihat.

\section{KESIMPULAN DAN SARAN \\ 1.Kesimpulan}

Karya tari yang berjudul Sa Pangambe Sa Panili merupakan upaya untuk memberikan nilai positif kepada masyarakat Mandailing Natal. Nilai-nilai positif yang ditampilkan berpijak pada kegiatan ritual Marpangir yang dilakukan oleh nenek moyang pada zaman dahulu. Karya ini tidak hanya pengolahan tubuh saja namun perwujudan gerak melalui penjelajahan 
nilai tradisi seperti gerakan Tor-tor. Konsep garapan karya ini adalah pergeseran nilai dari kegiatan ritual Marpangir yang ada di Mandailing Natal. Jumlah penari keseluruhan pada karya ini adalah 16 penari, 6 penari tradisi diantaranya tiga penari laki-laki dan tiga penari perempuan, lalu 10 penari kontemporer diantaranya lima penari laki-laki dan lima penari perempuan. Alat musik yang digunakan pada tari Tortor Naposo Nauli Bulung adalah Gordang Sambilan, Seruling, Cak-cak, Gong, Talempong dan syair.

Busana yang digunakan penari perempuan tarian tradisi adalah baju kurung warna hitam khas Mandailing, rok songket merah, Parompa Sadun yang dililit ditubuh, lalu menggunakan asesoris Gaja Meong, tali pinggang, selendang Parompa Sadun dan Jagar-Jagar. Penari laki-laki menggunakan baju kemeja putih, celana hitam, songket merah, peci dan Parompa Sadun yang dililit ditubuh. Busana yang digunakan penari perempuan tari kontemporer adalah baju kurung abu-abu, baju kurung merah, celana hitam, rok hitam dan penutup kepala, lalu penari laki-laki menggunakan baju lengan pendek hitam, baju lengan panjang hitam, celana pendek abu-abu dan celana panjang abu-abu. Melalui karya ini terlihat bagaimana pergeseran nilai dari kegiatan Marpangir. Syair pada Gordang Sambilan, syair pada Ungut-ungut dan lirik puisi memiliki nasehat dan aturan-aturan yang ada di Mandailing Natal.

\section{Saran}

Karya seni memiliki penilaian yang berbeda di mata penikmat seni. Suatu karya seni juga memliki makna yang luas dan sesuai dengan siapa yang melihatnya. Tidak dapat memaksakan interpretasi penonton terhadap karya yang diciptakan. Penonton bebas mengartikan karya yang telah diciptakan itu sesuai dengan sudut pandang dan imajinasi masing-masing penonton.

Mengingat banyaknya karya seni baru yang berkembang di masyarakat yang bukan berpijak pada budaya Mandailing Natal demi mengupayakan pelestarian budaya yang masih bisa kita pertahankan sampai sekarang diharapkan kedepannya mampu mengemas karya tari baru dengan berlandaskan budaya Mandailing, sehingga generasi muda tertarik dan mau melestarikan budaya.

Peran pemerintah Kab. Mandailing Natal senantiasa memberikan motivasi kepada masyarakat luas dan seniman untuk selalu mempertahankan adat dan budaya kita. Untuk mengemas adat dan budaya bisa melalui tarian, musik, rupa dan drama, sehingga
Gorga : Jurnal Seni Rupa

Volume 10 Nomor 02 Juli-Desember 2021

p-ISSN: 2301-5942 | e-ISSN: 2580-2380

masyarakat bisa tahu adat dan budaya Mandailing Natal yang sebenarnya.

\section{DAFTAR RUJUKAN}

Dharsono. (2016). Kreasi Artistik: Perjumpaan Tradisi Modern Dalam Paradigma Kekaryaan Seni. Yogyakarta: Citra Sain.

Efendi, Erwin. (2017). "Sa Pangambe Sa Panaili". Hasil Wawancara Pribadi: 03 Oktober 2017, Mandailing Natal.

Hadi, Y. Sumandiyo. (2003). Mencipta Lewat Tari. Yogyakarta: Manthil.

Hasan, Alwi dkk. (1990). Kamus Besar Bahasa Indonesia Edisi I. Jakarta: Balai Pustaka.

Hidajat, Robby. (2008). Pengantar Teori Dan Praktek Menyusun Tari Bagi Guru. Malang: Jurusan Seni \& Desain Fakultas Sastra Universitas Negeri Malang.

Muslim. (2017). "Sa Pangambe Sa Panaili". Hasil Wawancara Pribadi: 12 Oktober 2017, Mandailing Natal.

Murgiyanto, Sal. (1993). Ketika Cahaya Merah Memudar. Jakarta: CV Deviri Ganan.

Sari, Lucky Pesona. (2020). Nelangsa. Padangpanjang: Pascasarjana Institut Seni Indonesia Padangpanjang.

Sugianto. (2021). "Pakaian dan Aksesoris". Hasil Dokumentasi Pribadi: 13 Maret 2021, Panyabungan. 